\title{
Transfusion of blood products in off-pump coronary artery bypass and conventional coronary artery revascularization. A prospective randomized study
}

\author{
Maciej Walczak ${ }^{1}$, Tomasz Kamil Urbanowicz², Jadwiga Tomczyk², Estillita Camacho ${ }^{2}$, Marcin Ligowski², \\ Sebastian Stefaniak², Marek Jemielity ${ }^{2}$ \\ ${ }^{1}$ Cardiac Surgery and Transplantology Department, Chair of Cardio-Thoracic Surgery, Poznan University of Medical Sciences, \\ Poland \\ ${ }^{2}$ Cardiac Surgery Department, University Hospital of Lord's Transfiguration, Poznan, Poland
}

Kardiochirurgia i Torakochirurgia Polska 2014; 11 (2): 136-139

\begin{abstract}
Introduction: There has been a growing interest in off-pump coronary artery bypass (OPCAB) grafting in recent years. Beating-heart surgery is believed to be less invasive as it allows the side effects of extracorporeal circulation to be avoided.

The aim of the study was to compare blood product transfusion rates between two groups of patients undergoing surgery for ischemic heart disease with either the off-pump technique or using cardiopulmonary bypass (CPB).

Material and methods: There were 152 patients enrolled in the prospective randomized study. All procedures were elective. There were 84 patients ( 62 men and 20 women) at the mean age of $63.74 \pm 7$ years who underwent OPCAB (group I), and 68 patients ( 54 men and 14 women) at the mean age of 63.51 \pm 6 years who underwent cardiopulmonary bypass (group II). Results: There were no perioperative deaths. The mean number of grafts was $2.27 \pm 0.3$ (OPCAB group) and $2.63 \pm 0.6$ (CPB group) $(p<0.05)$. The mean number of packed red blood cells transfused in the OPCAB group was $2.31 \pm 0.18$ units/patient and $3.94 \pm 0.30$ units/patient in the CPB group $(p<0.05)$. The mean number of fresh frozen plasma units transfused was $1.13 \pm 0.13$ in the OPCAB group vs. $1.57 \pm 0.15$ in the $C P B$ group $(p<0.05)$. There were 12 patients $(14 \%)$ in the OPCAB group who had no transfusion.

Conclusions: One of the most important advantages of the OPCAB technique is that it makes it possible to reduce the rate of blood product transfusions.
\end{abstract}

Key words: myocardial revascularization, $\mathrm{OPCAB}, \mathrm{CPB}, \mathrm{CABG}$ blood products, transfusion.

\section{Streszczenie}

Wstęp: W ostatnich latach coraz częściej wprowadza się do leczenia chirurgicznego choroby wieńcowej zabieg pomostowania aortalno-wieńcowego bez użycia krążenia pozaustrojowego (off-pump coronary artery bypass - OPCAB). Zabieg przeprowadzany na bijącym sercu uważa się za mniej inwazyjny, ponieważ pozwala uniknąć efektów ubocznych związanych ze stosowaniem krążenia pozaustrojowego.

Celem badania było porównanie ilości przetaczanych preparatów krwi w dwóch grupach pacjentów operowanych z powodu choroby niedokrwiennej serca przy użyciu techniki pomostowania aortalno-wieńcowego bez użycia krążenia pozaustrojowego lub z użyciem krążenia pozaustrojowego (cardiopulmonary bypass - CPB).

Materiat i metody: Do prospektywnego badania z randomizacją zakwalifikowano 152 pacjentów. Wszystkie zabiegi przeprowadzono w trybie elektywnym. Grupa I składała się z 84 osób (64 mężczyzn i 20 kobiet), w średnim wieku 63,74 \pm 7 lat, które poddano zabiegowi z użyciem techniki OPCAB, a grupę II tworzyto 60 osób (54 mężczyzn i 14 kobiet), w średnim wieku 63,51 \pm 6 lat, które poddano zabiegowi z użyciem płucoserca (CPB).

Wyniki: Śródoperacyjnie i we wczesnym okresie pooperacyjnym nie obserwowano przypadków śmiertelnych. Średnia liczba wykonanych pomostów wyniosła 2,27 \pm 0,3 (grupa OPCAB) i 2,63 \pm 0,6 (grupa operacji w krążeniu pozaustrojowym/grupa CPB $(p<0,05)$. Średnia liczba jednostek koncentratu krwinek czerwonych podanych $w$ grupie OPCAB wyniosła 2,31 $\pm 0,18$ jednostek na pacjenta, a w grupie CPB $-3,94 \pm 0,30$ jednostek na pacjenta $(p<0,05)$. Średnia liczba jednostek świeżo mrożonego osocza wyniosła 1,13 $\pm 0,13$ w grupie OPCAB i $1,57 \pm 0,15$ w grupie CPB $(p<0,05)$. U 12 pacjentów $(14 \%)$ w grupie OPCAB nie wykonano transfuzji.

Wnioski: Istotną zaletą techniki OPCAB jest związana z nią możliwość zmniejszenia częstości transfuzji preparatów krwi. Słowa kluczowe: rewaskularyzacja mięśnia sercowego, OPCAB, CPB, CABG, preparaty krwi, transfuzja.

Address for correspondence: Tomasz Urbanowicz, MD, PhD, Długa 1/2, 61-848 Poznań, Poland, tel. +48 618549233 ,

e-mail: tomasz.urbanowicz@skpp.edu.pl 


\section{Introduction}

Cardiovascular diseases are the leading cause of death in Poland. Among them, ischemic heart disease poses one of the largest challenges [1].

Recent years have seen a growing interest in off-pump coronary artery bypass surgery. The majority of cardiac procedures are performed on cardiopulmonary bypass, with blood transfusions being part of the procedure [2]. As the extracorporeal circulation causes many side effects involving blood components, the restoration of hemoglobin concentration by means of transfusion is almost always essential [3]. The majority of heart surgery complications are reported to be related to cardiopulmonary bypass [4] Systemic inflammatory response syndrome (SIRS) is usually self-limiting and may involve most organs [5, 6].

Hemostatic disturbances secondary to CPB may cause such serious complications as disseminated intravascular coagulation (DIC) $[7,8]$.

\section{Material and methods}

There were 152 patients (118 men and 34 women) at the mean age of $63 \pm 14$ years enrolled in the study. The patients were divided into the OPCAB group and the CPB group. The OPCAB group included 84 patients (64 men

Tab. I. Demographical and perioperative data

\begin{tabular}{lccc} 
Data & $\begin{array}{c}\text { OPCAB group } \\
n=84\end{array}$ & $\begin{array}{c}\text { CABG group } \\
n=68\end{array}$ & \\
Demographical & & & \\
\hline Age & $64 \pm 7$ & $63 \pm 6$ & $\mathrm{~ns}$ \\
\hline Gender (M/F) & $64 / 20$ & $54 / 14$ & $\mathrm{~ns}$ \\
\hline Risk factors & & & \\
\hline DM & $14(17 \%)$ & $11(16 \%)$ & $\mathrm{ns}$ \\
\hline Stroke & $2(2 \%)$ & $2(3 \%)$ & $\mathrm{ns}$ \\
\hline Peripheral disease & $4(5 \%)$ & $4(6 \%)$ & $\mathrm{ns}$ \\
\hline COPD & $7(8 \%)$ & $5(7 \%)$ & $\mathrm{ns}$ \\
\hline Smoking history & $16(19 \%)$ & $12(17 \%)$ & $\mathrm{ns}$ \\
\hline Arterial hypertension & $42(50 \%)$ & $31(45 \%)$ & $\mathrm{ns}$ \\
\hline Clinical & & & \\
\hline Vessel disease & & & $\mathrm{n}$ \\
\hline LMCA & $10(12 \%)$ & $8(12 \%)$ & $\mathrm{ns}$ \\
\hline 2 vessels disease & $22(26 \%)$ & $24(34 \%)$ & $p<0.05$ \\
\hline 3 vessel disease & $52(62 \%)$ & $36(53 \%)$ & $p<0.05$ \\
\hline LVEF & $57 \pm 4 \%$ & $53 \pm 6 \%$ & $\mathrm{~ns}$ \\
\hline preoperatively & $59 \pm 6 \%$ & $54 \pm 7 \%$ & $\mathrm{~ns}$ \\
\hline No of grafts & & & \\
\hline
\end{tabular}

and 20 women) at the mean age of $64 \pm 7$ years and the CPB group included 68 patients (54 men and 14 women) at the mean age of $63 \pm 6$ years. The mean preoperative left ventricular ejection fraction was $53 \pm 9 \%$ and $51 \pm 8 \%$, respectively. Demographic and clinical data are presented in Table I. All procedures were performed as a result of stable angina pectoris. Concomitant valvular pathology was the exclusion criterion. Preoperative laboratory tests showed no statistically significant difference between the groups. The serum hemoglobin concentration was $8.70 \pm$ $1.03 \mathrm{mmol} / \mathrm{L}$ in the OPCAB group vs. $8.78 \pm 0.70$ in the CPB group. The mean hematocrit values were $0.41 \pm 0.05$ in the OPCAB group vs. $0.42 \pm 0.03$ in the CPB group, ns. There was no difference in serum platelet concentration, which was $251.42 \pm 74.01 \mathrm{G} / \mathrm{L}$ in the OPCAB group vs. $228.04 \pm$ $59.78 \mathrm{G} / \mathrm{L}$ in the CPB group.

Heparin was administered at the dose of $2 \mathrm{mg} / \mathrm{kg}$ in the OPCAB group and $3 \mathrm{mg} / \mathrm{kg}$ in the CPB group, and the desired ACT was $350 \mathrm{~s}$ and $480 \mathrm{~s}$, respectively. Postoperatively, heparin was neutralized by protamine administered at the dose of $1 \mathrm{mg}$ per $1 \mathrm{mg}$ of heparin.

The CPB group was subsequently subjected to the procedures of ascending aorta and right atrium cannulation. Cardiopulmonary bypass was conducted in moderate hypothermia $\left(27-29^{\circ} \mathrm{C}\right)$ with cold, crystalloid cardioplegia administered antegrade in accordance with the St. Thomas Hospital formula.

In the OPCAB group, the Octopus $1 I^{\circledR}$ (Medtronic, USA) stabilization system was used and intraluminal shunts were applied during each distal anastomosis.

Red packed cells were transfused whenever serum hemoglobin was lower than $6.5 \mathrm{mmol} / \mathrm{L}(<10.5 \mathrm{~g} / \mathrm{dL})$.

\section{Statistical analysis}

The obtained data were entered and analyzed using the StatView 5.0 software (SAS Institute, Inc., Cary, NC, USA). The normality of data distribution was assessed using the Kolmogorov-Smirnov test. Continuous variables were described as mean values \pm SD and compared using Student's t-test or the Mann-Whitney $U$-test. The $\chi^{2}$ test or Fisher's exact test was chosen to compare categorical variables. To

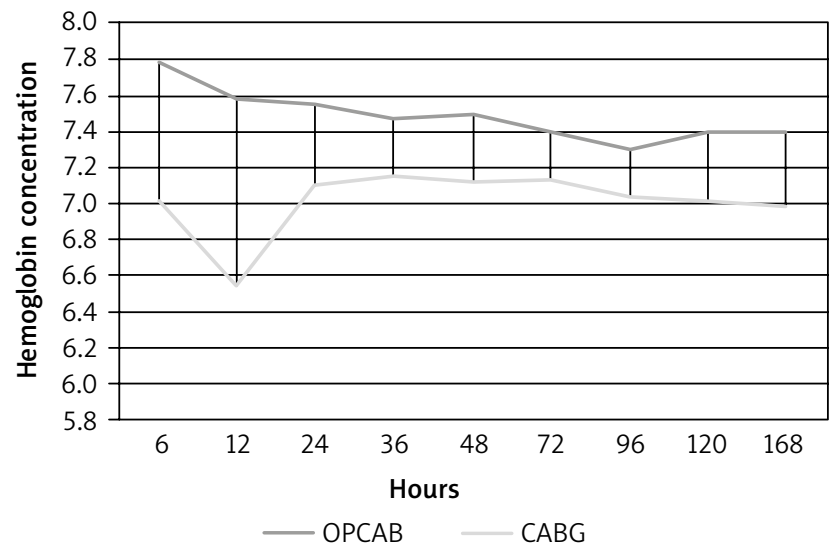

Fig. 1. Hemoglobin concentration after surgery in $O P C A B$ and $C P B$ group 
evaluate changes over time, we used repeated measures analysis of variance (ANOVA). Values of $p<0.05$ were considered significant.

\section{Results}

There were no perioperative deaths and no case of postoperative low cardiac syndrome was found in the study groups. There were 12 patients $(14 \%)$ in the OPCAB who did not require any blood product transfusions. Two reoperations $(2.4 \%)$ in the OPCAB group and three $(4.4 \%)$ in the CPB group were performed due to excessive bleeding $(p<0.05)$. The mean cardiopulmonary bypass time was 63 \pm 18 minutes and the mean cross clamping time was $43 \pm$ 11 minutes in the CPB group.

The mean packed red blood cells, fresh frozen plasma and platelet units transfused in the OPCAB group were 2.31 $\pm 0.18,1.13 \pm 0.13$ and $0.28 \pm 0.16$, respectively. The mean packed red blood cells, fresh frozen plasma and platelet units transfused in the CPB group were $3.94 \pm 0.30,1.57$ \pm 0.15 and $0.23 \pm 0.16$, respectively. There was a statistically significant difference in the mean packed red blood cells $(2.31 \pm 0.18$ vs. $3.94 \pm 0.30, p<0.05)$ and fresh frozen plasma (1.13 \pm 0.13 vs. $1.57 \pm 0.15, p<0.05)$ transfusion rate between the groups.

There was a difference in the mean serum hemoglobin concentration between the groups (OPCAB $7.79 \pm 0.91$ $\mathrm{mmol} / \mathrm{L}$ vs. CPB $7.03 \pm 0.88 \mathrm{mmol} / \mathrm{L}$ six hours after surgery, $p<0.05$ and OPCAB $7.47 \pm 1.10 \mathrm{mmol} / \mathrm{L}$ vs. CPB $7.17 \pm 0.99$ $\mathrm{mmol} / \mathrm{L}$ one day after surgery). Figure 1 presents the differences in the serum hemoglobin concentration between the groups after surgery. The platelet count was comparable before the procedure $\left(199 \pm 6110^{3} / \mathrm{L}\right.$ vs. $178 \pm 4110^{3} / \mathrm{L}$ in the OPCAB and CPB group, respectively). The platelet count after surgery decreased progressively from $205 \pm 5610^{3} / \mathrm{L}$, $192 \pm 5310^{3} / \mathrm{L}$ one day after surgery to $169 \pm 5710^{3} / \mathrm{L}$ on the $7^{\text {th }}$ postoperative day. On the other hand, the platelet count after surgery increased progressively in the CPB group from the initial $155 \pm 4110^{3} / \mathrm{L}, 165 \pm 4310^{3} / \mathrm{L}$ one day after surgery to $369 \pm 7210^{3} / \mathrm{L}$ on the $7^{\text {th }}$ postoperative day.

There was also a statistically significant difference in postoperative drainage between the two groups (OPCAB: $755.54 \pm 42.82 \mathrm{~mL}$ vs. CPB: $895.74 \pm 47.35 \mathrm{~mL}, p<0.05)$.

\section{Discussion}

The first successful use of the heart-lung machine on humans occurred in 1953, when John Gibbon performed surgery on a 15-month-old girl, Celia Bavolek, at Jefferson Hospital in Philadelphia [9].

Eleven years later, in 1964, the Russian surgeon Kolessov performed the first successful heart bypass surgery on a beating heart [10]. Surgical revascularization was soon demonstrated to provide excellent survival results and relief of symptoms $[11,12]$.

Renewed interest in beating-heart bypass grafting in the mid-1990s resulted from the option of revascularization without the potential complications of extracorporeal support. Although the theoretical advantages of OPCAB
Tab. II. Blood products transfusions

\begin{tabular}{lccc} 
Blood products & OPCAB group & CABG group & \\
Red cells (units) & $2.31 \pm 0.2$ & $3.94 \pm 0.3$ & $<0.05$ \\
\hline $\begin{array}{l}\text { Fresh frozen plasma } \\
\text { (units) }\end{array}$ & $1.13 \pm 0.13$ & $1.57 \pm 0.15$ & $<0.05$ \\
\hline Platelets (units) & $0.28 \pm 0.16$ & $0.23 \pm 0.16$ & $\mathrm{~ns}$ \\
\hline
\end{tabular}

procedures are generally accepted, the use of this technique still remains sporadic. For example, off-pump surgery constitutes only 20 to $25 \%$ of all coronary artery bypass procedures performed in the United States [13].

A debatable issue is that of graft patency rates, which seem to be at least equivalent to those observed in the case of conventional techniques. The advantage of offpump coronary artery bypass can be supported by such important factors as reduced morbidity and mortality, rapid return to usual functional capacity, and economic benefits. Unfortunately, a lot of data reported in the literature concerning the outcomes of off-pump bypass grafting have been inconclusive as to the overall benefit of the technique. Most studies have suffered from the fact that they have been retrospective reviews. Although the OPCAB technique eliminates cardiopulmonary bypass and hypothermic cardiac arrest, the manipulation of the ascending aorta by partial clamping has for the most part not been eliminated.

So far, there have been 37 randomized clinical trials published, comparing OPCAB versus conventional CABG. No randomized trials have shown a significant reduction in the occurrence of stroke or myocardial infarction, acute renal failure, intra-aortic balloon pump (IABP) requirement, mediastinitis or wound infection, the recurrence of angina, or the need for reintervention within 30 days of OPCAB, in comparison with conventional CABG [14]. Similar results were obtained at 1 and 3 years after surgery [15].

In the present study, there was a reduction of blood cell product transfusions in the OPCAB group, as compared to the CPB group (Table II). OPCAB procedures make it possible not only to limit the number of transfusions but to eliminate transfusions altogether $[16,17]$. The elimination of blood product transfusion can be essential in the case of patients with religious restrictions, such as Jehovah witnesses [18].

The serum hemoglobin concentration in the OPCAB group remains stable throughout the postoperative period, as presented in Table I. At the same time, we can observe a decline in the hemoglobin concentration in conventional CABG patients until the $12^{\text {th }}$ postoperative hour. The restitution of the hematocrit level was achieved by administering packed red cell transfusions thereafter.

\section{Conclusions}

Off-pump surgery allows for reducing the rate of blood product transfusions or eliminating them altogether. The hematocrit level remained more stable during the postoperative period in the OPCAB group. Patients undergoing 
conventional CABG surgery were characterized by higher postoperative drainage, presumably due to more serious coagulation disturbances.

\section{References}

1. Sadowski J, Kapelak B, Wierzbicki K. Coronary artery disease - classic and modern surgical treatment. Terapia 2003; 3: 4-8.

2. Wites MM. Zastosowanie krwi i jej preparatów w kardiochirurgii - stan aktualny i kierunki rozwoju w oparciu o 20-letnie obserwacje kliniczne. Magazyn Medyczny 1999; 4: 13-14.

3. Zych B, Pacholewicz J, Farmas A, Saucha W, Hrapkowicz T, Zembala M. Operacje kardiochirurgiczne przetoczenia krwi i środków krwiopochodnych. Kardichir Torakochir Pol 2004; 1: 31-40.

4. Rogowski J, Jarmoszewicz K, Siondalski P, Pawlaczyk R. Opieka pooperacyjna po zabiegach kardiochirurgicznych. Choroby Serca i Naczyń 2006; 3: 115-122.

5. Suwalski G, Filipiak KJ. Uogólniona odpowiedź zapalna u chorych poddanych zabiegom chirurgicznej rewaskularyzacji mięśnia sercowego. Polski Przegląd Kardiologiczny 2002; 4: 259-266.

6. Ascione R, Lloyd CT, Underwood MJ, Lotto AA, Pitsis AA, Angelini GD. Inflammatory response after coronary revasscularization with or without cardiopulmonary by-pass. Ann Thorac Surg 2000; 69: 1198-1204.

7. Khuri S, Wolfe JA, Josa M, Axford TC, Szymanski I, Assousa S, Ragno G, Patel $M$, Silverman A, Park M. Hematologic changes during and after cardiopulmonary bypass and their relationship to the bleeding time and nonsurgical blood loss. J Thorac Cardiovasc Surg 1992; 104: 94-107.

8. Czapla J, Skalski JH. Zaburzenia hemostazy w kardiochirurgii. In: Kardiochirurgia dziecięca. Tom I. Skalski J, Religa A (eds.). Wydawnictwo Śląsk, Katowice 2003; pp. 96-309.
9. Gibbon JH Jr. Application of a mechanical heart and lung apparatusto cardiac surgery. Minn Med 1954; 37: 171-180.

10. Kolessov VI. Mammary artery-coronary artery anastomosis as method of treatment for angina pectoris. J Thorac Cardiovasc Surg 1967; 54: 535-544.

11. European Coronary Surgery Study Group. Long-term results of prospective randomised study of coronary artery bypass surgery in stable angina pectoris. European Coronary Surgery Study Group. Lancet 1982; 2: 1173-1180.

12. The Veterans Administration Coronary Artery Bypass Surgery Cooperative Study Group. Eleven-year survival in the Veterans Administration randomized trial of coronary bypass surgery for stable angina. N Engl J Med 1984; 311: 133-139.

13. Lytle BW, Sabik JF. On-pump and off-pump bypass surgery: Tools for revascularization. Circulation 2004; 109: 810-812.

14. Sellke FW, DiMaio JM, Caplan LR, Ferguson TB, Gardner TJ, Hiratzka LF, Isselbacher EM, Lytle BW, Mack MJ, Murkin JM, Robbins RC. Comparing onpump vs off-pump coronary artery bypass grafting: Numerous studies but fewer conclusions. Circulation 2005; 111: 2858-2864.

15. Reston JT, Tregear SJ, Turkelson CM. Meta-analysis of short-term and midterm outcomes following off-pump coronary artery bypass grafting. Ann Thorac Surg 2003; 76: 1510-1515.

16. Angelini GD, Taylor FC, Reeves BC, Asciore R. Early and midterm outcome after off-pump and on-pump surgery. In Beating Heart Against Cardioplegic Arrest Studies (BHACAS 1 and 2): a pooled analysis of two randomised controlled trials. Lancet 2002; 359: 1194-1199.

17. MacGilivrary TE, Vlahakes GJ. Patency and the pump - the risk and benefis of off-pump CABG. N Engl J Med 2004; 1: 3-4.

18. Juraszek A, Dziodzio T, Roedler S, Kral A, Hutschala D, Wolner E, Grimm M, Czerny M. Results of open heart surgery in Jehovah's Witnesses patients. J Cardiovasc Surg 2009; 50: 247-250. 